\title{
The Humanist Roots of Islamic Administration and Leadership for Education: Philosophical Foundations for Intercultural and Transcultural Teaching
}

\author{
Eugenie A. Samier
}

\begin{abstract}
This chapter examines the Islamic humanist tradition as it relates to the teaching of educational administration and leadership in a Muslim context, with implications for intercultural and transcultural use and to show correspondences with Western humanism. The initial section is a comparison of the central principles of the Islamic humanist tradition from the classical through to contemporary times with the Western humanist tradition as they relate to conceptions of the good, ethics, the construction of meaning and a set of higher order values predicated upon human dignity, integrity, empathy, well-being, and the public good. In both, professions are viewed as meaningful work that allow for large measures of decision making, and are grounded in human qualities and needs including autonomy, freedom and emancipation balanced with responsibilities, obligations and duties to society. These are compared with principles of knowledge in Western humanism. Secondly, the chapter examines the principles of good or ideal leadership and administration that humanism aims at in its preparation of officials, including those in the educational sector in the classical Islamic tradition. The chapter concludes with a discussion of how the Islamic humanist tradition can contribute to intercultural and transcultural graduate teaching in international educational administration.
\end{abstract}

\section{Introduction}

For a number of decades, humanism has been a minor but persistent approach in the Western field of administrative and leadership studies, and only recently has broadened to include other international humanist traditions (Dierksmeier et al. 2011). However, the development in education, particularly in non-Western contexts (e.g., Arar and Haj-Yehia 2018) is not as developed as humanism in business management, which has produced a number of books that provide a comprehensive approach (e.g., Spitzeck et al. 2009; Von Kimakowitz et al. 2011) including management and leadership education (Amannet et al. 2011). There are humanist texts

E. A. Samier

e-mail: eugenie.samier@gmail.com 
in educational studies relevant to administration and leadership such as early theoretical foundations (Greenfield and Ribbins 1993; Samier 2005), humanisation as a necessary precondition for peace education often associated with critical perspectives like that of Friere (Gill and Niens 2014), in McLaren and Jamillo's (2007) promotion of a critical humanistic approach to the effects of global capitalism on education, and recently in the critique of neoliberal managerial administration of education that undermines humanistic foundations (Plum 2012). There are also international and comparative educational leadership arguments like those of Wong (1998) that moral humanism is a central feature of other cultures like Chinese which do not receive enough attention in the field in the West. A fuller exploration of humanism's effect on pedagogy and curriculum needs both a broader development in the contemporary world as well as a more comprehensive appreciation of several historical traditions - here its Islamic roots are explored.

Arguments for a return to humanism include the lack of intellectual depth and domination by a market-based business model (Niesche 2018). Another comes from the critique of neoliberalism and its internationalisation through globalised education where all but economic values are held as a priority and even serve as the underlying foundation for management and leadership models (Mullen et al. 2013), which also account for damaging effects on indigenous systems of belief critiqued in the postcolonial literatures, for example, the marginalisation of humanist Ubuntuism in a number of African communities (Barongo-Muweke 2016). Beekun (2012, p. 1003) sees, for example, the Islamic emphasis on character, morality and related values as a more valuable foundation for management than the current business(-derived) models that are predicated upon 'self-serving, individualistic and narcissistic tendencies.' Humanism has been a foundational philosophy from which other theories of education and its management have derived in many parts of the world, some of which still have influence in their communities like Confucianism and Islam which have given rise to intellectual traditions, research, the formation of educational systems, and from which we can learn in an increasingly diversified world (Samier forthcoming).

The focus in this chapter is on the Islamic humanist tradition as it relates to the teaching of educational administration and leadership in a Muslim context, with implications for intercultural and transcultural use. As a number of scholars are beginning to point out, educational administration and leadership is not solely an Anglo-American topic as it has tended to be framed 
for the last few decades, but has many historical and international antecedents (Arar and Haj-Yehia 2018). The second purpose of the chapter is to show the correspondences that exist between the Islamic and Western humanist traditions in terms of human values, knowledge and educational ideal, which in this chapter are argued to be close in many ways to the Western Idealist tradition and the German Bildung conception of education, despite significant differences that may provide avenues of understanding in multicultural environments.

\section{Humanistic Principles in Islam and the West}

The purpose of this section is to identify the core values and principles of humanism in the West and Islam, including their historical relationship, and to discuss in more detail the forms it takes in Islamic leadership and administration. Although the traditions in the West and Islam are related, through similar ideas of the good, ethics, the construction of meaning, and a set of higher order values predicated upon human dignity, integrity, empathy, well-being and the public good (Goodman 2003), they do differ in a few significant ways. But in both, professions are viewed as meaningful work that allow for large measures of decision making, and are grounded in human qualities and needs including autonomy, freedom and emancipation balanced with responsibilities, obligations and duties to society.

\section{Humanism in the West}

The concept of humanism in the West refers primarily to the Renaissance movement of valuing human beings and the culture and values that place humanity in the centre of considerations, coming to mean a non-religious or secular perspective by the modern period, although by the midtwentieth century, took on a broader view that reflected interest internationally in systems of thought as a recognition that the values associated with Western humanism were shared by other traditions (Copson 2015). What is shared is a moral and political concern for the welfare of human beings, their ability to use reason, express their views and concerns, and work to construct a world in which individuals can reach their full human potential. The degree to which this rests on a 'scientific' approach to reality has been disputed by interpretive and critical approaches that distinguish between science as a value and method for knowing the natural world and 
understanding that is used to learn about human life and whether humanism is necessarily secular and non-religious (see Nasr 2006; Oldmeadow 2003) is a contentious point, with which some have taken issue, particularly in humanism's development historically within religious systems of thought (Zimmerman 2012). However, the view taken here is that early humanism and continuing as a tradition within the field, is that humanistic knowledge can be grounded in direct spiritual experience. The historical relationship of Western and Islamic scholarship (e.g., Al-Rodhan 2012; Essa 2010) is a close shared tradition through humanist and liberal arts traditions where the influence is strongest with respect to conceptions of peace and cosmopolitanism (Küng 2008; March 2009; Said 2004; Tampio 2012) with respect to conceptions of peace and cosmopolitanism, and in principles of public policy (Karim and Eid 2014).

Depending on the form of humanism, a variety of character and personality traits as well as styles of social interaction are considered in the human interest. The main values of humanism focus on the human condition as the relate to peace, justice, equality and human rights along with tolerance and personal responsibility in a world that is humanly created at least on a socio-political and cultural level. This necessitates the cultivation of human reason, awareness, decision making and choice in order for people to achieve their ideals and aspirations, create meaning, and cultivate virtues of character. What is also closely associated with this approach are capacities of sympathy and empathy as well as a critical and interpretive understanding of society and its social institutions (Grayling 2015).

Humanism, as it is interpreted for application to leadership and management studies, focusses on a few key principles: respect for the dignity of each person to prevent exploitation and abuse (Pirson and Kostera 2017); ethical decision making as the foundation of business practices that derives from a Kantian-type view that people are ends in themselves rather than means to goals, an approach that characterises many management models; and normative legitimacy in business for contributing positively to society and meeting corporate responsibilities rather than the selfinterest that often dominates corporate culture (Von Kimakowitz et al. 2011). The shift in perspective is one from the market, efficiency and exchange values to human and societal wellbeing as intrinsic values focused on human rights, the elevation of ethics to a position of primacy, and the use of the humanities in education and research in constructing knowledge and achieving 
cultural sensitivity. Amann and Stachowicz-Stanusch (2013) emphasise integrity as a core humanistic value that should govern organisations in achieving dignity, through three means that affect social interaction particularly affecting leadership roles: overcoming organisational inconsistencies in 'actions, values, methods, measure, principles, expectations, and outcomes' in humanism; closing gaps that exist between behaviour and appropriate societal norms; and overcoming the incompatibilities between the organization's structures and practices that compromise moral principles (p. 3).

A humanistic approach initially developed in many Western countries as an investigation of their administrative systems focused on the (quasi-humanistic) Human Relations movement followed by Organizational Humanism (Kaplan and Tausky 1977) and subsequently by more participatory forms of leadership, debureaucratising to humanise public agencies (Gagliardi and Czarniawska 2006), and managing with integrity (Amann and Stachowicz-Stanusch 2013) while emphasising interpretivism, hermeneutic and phenomenological approaches as well as emancipatory critical theory (Box 2005) and using the humanities in teaching management fields (e.g., Brown 1994; Czarniawska-Joerges and Guillet de Monthoux 1994). Similar concepts have been explored in educational administration (Greenfield and Ribbins 1993; Samier 2005). While it is common in the literature to find humanism associated with the 'Western' tradition (Antweiler 2012), there are other humanisms in addition to the Islamic which also have relevance for administrative studies, such as African, Indian and Chinese societies (e.g., Copson and Grayling 2015; Dierksmeier et al. 2011; Leoussi 2000; Schiele 1990).

Humanism in educational administration and leadership in the West rests partly on the foundation of literature on humanism in education generally, such as Veugelers (2011; see also Aloni 2007; Steiner 2004) for whom autonomy combined with humanity in education allows one to have agency and assume personal responsibility guided by moral principle, developing one's capacity and contributing to the welfare of others. In more politically radical form it is aimed at emancipation in Freire (Roberts 2000). In educational administration, the first major scholar to open the door theoretically and practically to humanism was Thom Greenfield (Greenfield and Ribbins 1993) who began his transformation from the dominant structural-functionalism towards a humanistic perspective in the 1970s developing towards an existential view grounded in classical 
thought and mostly the idealist intellectual tradition, followed by a few authors like Maxcy (1983) and Ribbins (2003). While the field has not engaged in detail in humanism, it has produced a body of literature that strives for a 'humane' model (e.g., Aloni and Weintrob 2017; Giancola and Hutchison 2005), and is associated with neo-Marxist (Smyth 1989) and critical theory (Foster 1986) humanism through feminist critiques (Blackmore 1999), social justice (Lumby and Coleman 2007), and a broad range of critical perspectives like Bourdieu (Thomson 2017), Foucault (Gillies 2013), Arendt (Gunter 2014), and is reflected in many postcolonial approaches (e.g., Rhea 2015) encompassing the main values of humanism regarding dignity, freedom, peace, tolerance, equality and a sensitivity to human qualities, both positive and negative.

\section{Humanism in Islam}

Humanism's relevance to leadership and management is not new to the Islamic tradition. Many passages in the Qur'an and Hadith were intended to apply to the economic sector by seeking to ground business practices in morality as an application of fundamental principles of rights, justice and equity, tolerance and harmoniousness for society. The texts are specific in their application itemising guidelines for contracts, transactions, jurisprudential guidelines and procedures, and identifying forms of business that were morally desirable as well as character traits that met these standards (Mohammed 2013). One can also infer from the Prophet Muhammad's actions and speech that his purpose of inviting others to the good and right, provides a model of appropriate leadership in others, which in an organisational context can be understood as creating a culture and work that allows others to develop into their full potential within a moral framework. A broad range of behaviour was itemised as undesirable and therefore immoral (haram) such as greed, the misuse of wealth in damaging others and the community, using violence, and maligning others, all of which are inconsistent with the Qur'anic conception of good character consisting of goodness, righteousness, equity, harmony and justice, the truth and the right, and piety (Mohammed 2013). Those in leadership positons should be governed by integrity and honesty with a duty to compassion and protecting others (ElKaleh and Samier 2013).

Social justice is at the heart of this tradition, observed by Mir (2010) to consist of a vision for leadership of shaping a society that is just, egalitarian, and welfare-oriented and free from 
oppression and discrimination. Mir compares the Islamic leadership model consisting of the attributes of piety, humility, social responsibility, self-development and mutual consultation, as mostly closely related to Burns' (1978) conception of transforming leadership since its primary responsibility is that of raising others to higher moral and motivational levels.

These central humanistic Islamic concepts were expressed by a large number of scholars beginning in the earliest years of the Islamic medieval intellectual tradition, among the best known being $\mathrm{Al}$ Farabi, Al Ghazzali, Ibn Khaldun, Al-Kindi, Ibn Miskawayh, Ibn Sina and Ibn Rushd (Goodman 2003; Pormann 2010) reflecting a constructivist view of reality (Makdisi 1990; Morgan, 1980), and heavily grounded in classical philosophy, particularly Plato and Aristotle. The religious philosophy of Al-Farabi and Ibn Sina, for example, was influenced heavily by the work of Aquinas, Augustine, Spinoza and Leibniz and the scientific writing in turn of Ibn Sina influenced Bacon among many others (Al-Khalili 2010; Lyons 2009; Masood 2009; Morgan 2007) particularly from the $9^{\text {th }}$ through to the $13^{\text {th }}$ centuries in what is referred to as the European Renaissance. During this period many Christian, Jewish and Muslim scholars and monks visited centres of learning like Baghdad, Basra, Isfahan and in Al Andalus for whom knowledge was regarded as belonging to all of humanity (Leaman 1996; Ljamai 2015). It was a scholarly tradition that formed mostly in the Abbasid caliphate where rulers and senior officials heavily patronised education, the establishment of research centres and universities, and a community of scholars during which the major disciplines and scholarly schools formed and whose work translated classical philosophy and built upon its foundation. In the midst of this explosion of research and thought, the humanistic character of Islam was expanded on and formed the basis of the humanities and social sciences as well as some of the legal and religious commentary traditions.

What unites them, to varying degrees in their emphases, is the role of reason in producing knowledge and morality (Kraemer 1984) (although there was and still is controversy within Islamic scholarship on the relationship been rationality and religious doctrine of revelation), a concentration on the nature of humanity and its capacities, and the possibilities of education in producing the cultured, enlightened and knowledgeable human being, as well as a tradition of 'perennial wisdom' (Leaman 1996). What also distinguished them was their understanding of education and its essential role in producing a good and moral society through shaping individuals 
in education morally and intellectually as well as acquiring the knowledge and skills to participate fruitfully in society (Kraemer 1984).

\section{The Humanistic Ideal of Islamic Educational Administration and Leadership}

The central concept of 'adib' - what education and experience is necessary in producing refined and cultured individuals - is roughly equivalent to the Greek notion of 'paideia' and the later German concept of 'Bildung', regarded as a necessary preparation in the Abbasid caliphate for the civil servants who served the empire (Leaman 1996). The main difference between the two, Leaman argues is not significant, with the Greek oriented towards the state, and the Muslim towards service to Allah in community and societal forms. What unites the two is the belief that reason is a path to morality and the social good, requiring an educational process that provides the capabilities and knowledge to perfect oneself in a union of theory and practice, and is a life-long pursuit that in Islam is a religious obligation in both the Qur'an and the Hadith (Günther 2006). It is in this tradition, producing a number of mirrors of princes that defined good rulership and public servant that Islamic humanistic models of leadership and administration are formed. It is during this period as well, that Aristotle's work among other classical writers on the nature and relationship of various bodies of knowledge were built upon in forming the disciplines and curriculum.

The close humanistic correspondence between Islamic and Western humanism is also evident in education through key concepts, approaches to fundamental human values, the construction of knowledge, and educational ideal as well as the kind of teaching practices that distinguish these traditions (Daiber 2013; Dossett 2014; Makdisi 1990) as they apply to humanistically-oriented educational administration and leadership. This tradition is still evident in contemporary scholars who advocate a humanistic educational ideal (Afsaruddin 2016; al-Attas 1980; Halstead 2004; Yasin and Jani 2013).

These principles were synthesised into a large body of curricular and pedagogical literature as scholarship expanded and an Islamic philosophy of education formed which discussed not only the aims and goals of education, but also teaching methods, how learning takes place, and the 
requisite actions and behaviour of students and teachers, particularly moral principles, which was understood to apply to all of those involved with education (Günther 2006) including those we would now identify as educational administrators and leaders. For example, Ibn Sahnun, whose influential 'Rules of Conduct for Teachers' (Adab al-mu'allimin) in the $9^{\text {th }}$ century specifies practices that overlap heavily into the educational administration role:

Ibn Sahnun provides to (medieval) elementary-school teachers a number of specific instructions and rules that range from aspects of the curriculum and examinations to practical legal advice in such matters as the appointment and payment of the teacher, the organization of teaching and the teacher's work with the pupils at school, the supervision of pupils at school and the teacher's responsibilities when the pupils are on their way home, the just treatment of pupils (including, e.g., how to handle trouble between pupils), classroom and teaching equipment, and the pupils' graduation. (Günther 2006, p. 370)

The principles of good or ideal leadership and administration that humanism aims at in its preparation of officials discussed above apply equally to those in the educational sector. The classical Islamic tradition has been explored for its role in schools connected to the leadership of the governing powers and their administrators including the role of humanist texts and the style of education used such as the 'work-study course' practice (Hassi 2012; Kashif et al. 2015; Makdisi 1990).

Arar and Haj-Yehia (2018) have investigated conceptions of Islamic medieval educational leadership and its potential value to contemporary multiculturalism. While the goals in Islamic education are not only for this life, but for the Day of Judgment, there are other values and concerns that are consistent with values one finds in a humanism that can be more broadly shared: ethical education, the influence on personality, supporting tolerance and diversity aimed at the social good, and moral behavior. In general, leaders in the tradition of Muslim communities should be oriented towards improving society and bringing cohesion to communities, including educational organisations, as well as practicing a form of praxis - in part derived from Aristotle in the classical Islamic tradition. Arar and Haj-Yehia (2018) have identified how in education, as in other spheres of life,), how Muslim leaders should be governed by a set of values and characteristics: practice 
collaboration, and encourage cooperation and collective responsibility; operate in accordance with Islamic values and Shari'ah law, including equality and justice; serve responsibly (derived from faith) and as a role model for the educational community; exhibit compassion, honesty, integrity and modesty, avoid deceit and discrimination, and other harmful practices; use hope and support to motivate teachers; and carry out administrative duties such as setting goals and putting into motion implementation through appropriate means, while using the principle of appointing the suitable person to the appropriate position. The character and disposition embedded in the conception of leader in the Islamic tradition has very high and multiple standards consisting of courage, durability, reliability, determination, stability, a scholarly orientation and have patience and inner peace with a well-developed ability in rhetoric.

Of most importance to this chapter are the principles of tolerance and pluralism embedded in Islam, and codified in the Shurūt 'Umar or the pact of Umar, which established the security and rights of minorities in an Islamic state, considered to be part of good governance (Krämer 2013). Even though its observance varied under individual regimes, many of the caliphs not only protected the rights of non-Muslims but appointed non-Muslims to very high positions in the bureaucracy (Sirry 2011) and later the Ottoman Empire maintained comparatively high levels of tolerance (Barkey 2005). Maintaining these principles in government and society are central responsibilities of those in political or institutional leadership positions.

\section{Conclusion}

There are a number of ways in which a knowledge of the Islamic humanist tradition's view of educational administration and leadership can contribute to both the scholarship and knowledge in the field as well as valuable practice-based understanding. On a more theoretical level, the Islamic tradition, along with many other traditions internationally and historically, can not only demonstrate that the field is contextually shaped, but also that some core conceptions and values, like humanistic ones can transcend cultural and historical boundaries. Secondly, it contributes to our understanding of other cultures and systems of thought and values, and intercultural and transnational knowledge from which we can learn. This can provide an important prophylaxis against ethnocentrism, bias, and even bigotry in both knowledge and value construction and in 
how this applies to shaping others' conceptions and practices in teaching the field, hopefully informing governance and policy making actors. It is a way in which a society can achieve the most fundamental rights of social justice; recognising other knowledge traditions is, I would argue, essential to respecting the dignity and integrity of others.

One way in which this can be done is to remember that the 'Western' tradition did not arise in isolation but rests upon foundations built by other parts of the world in intellectual history and is continually influenced by other traditions and scholars. This included a heavy debt to the classical period of Islamic scholarship, which not only conveyed large bodies of knowledge from classical Greek and Roman literature, their own advances in knowledge built upon this base and others, for example, India and China (Nasr 2001), but also the structure and organisation of the university as a social institution (Makdisi 1981) to Europe beginning in the late medieval period and continued through into the modern period. Given this foundational character of Western knowledge, it is argued here, that some Islamic and Western traditions should be seen as related, or, as Apostolov (2004) argues, zones of contact. It is this that allows for Islamic humanistic values to also serve as lessons in pursuing intercultural and transcultural practices and provide human commonality and bridges of understanding and cooperation.

This understanding can also help inform how the many critiques from other parts of the world than the West, and, mostly, Anglo-American scholarship in educational administration and leadership, in recognising them as valid, relevant, and legitimate concerns under historical and contemporary imperialism and globalisation: Orientalism, postcolonialism, subalternity, epistemicide, neoimperialism, colonisation of mind, cultural imperialism, Necrocapitalism, decolonisation, cultural security and symbolic violence (Samier and Milley unpublished paper). It is to these ruptures of Neoimperialism, aided by the reduction of all things to economic values in neoliberalism and seemingly the current world order, that inter- and transculturalism can speak. Even more of concern is the rising populist nationalism in many countries that builds walls, shuts down academic programmes and shuts out many groups of people, erecting exclusions that compromise social justice and contribute to violence (López-Alves and Johnson 2018). 
One can see that the humanistic dimension of the Islamic tradition provides the necessary values, knowledge and abilities for interculturalism and transculturalism to form in social relationships, and within professional roles and responsibilities. Interculturalism and transculturalism are two related but different phenomena. While definitions vary across literature in the field, in general terms, 'interculturalism' means having the values, knowledge and attitudes enabling people to engage in dialogue, exchange and interaction while maintaining their own cultural heritages, argued by many to reduce conflict and prejudice while increasing positive attitudes and evolve into solidarity (Loobuyck et al. 2016) - in other words producing what Portera (2011) calls a 'new synthesis' that allows one to interact morally across differences and can enter relationships on equal terms without having to sacrifice parts of their cultural identity. In effect, it is the ability for those of different cultures to engage in Habermasean (1984-1989) communicative action by equally exchanging ideas. However, as Cantle (2012) points out, intercultural dialogue by itself does not necessarily produce interculturality of community relations. The implications for educational administration and leadership are that knowledge and ability, as well as large measures of understanding and empathy, associated with humanism are required to engage interculturally with diverse colleagues, staff, students and parents. The measure of one's interculturality is not just an ability to be civil and tolerate other's views, but to engage in a formational relationship, even mentorship, with those from other cultural backgrounds, requiring a sense of common humanity and the cultural literacy and competencies (Cantle 2012) to do so. The record of the Islamic administrative tradition in its more humanistic phases, such as that of many periods in the Abbasid Caliphate, are evidence of a very high degree of intercultural cooperation and collaboration, as populations with the caliphate had the rights and protections for their national cultures and living alongside neighbours from other backgrounds, as well as the highly diverse senior bureaucracy drawn from many cultures and religious backgrounds who worked effectively together at high levels of administrative and leadership ability (Afsaruddin 2007; Samier 2017; Sirry 2011).

'Transculturalism', instead, refers to those elements of culture that travel across cultural boundaries, such as values like respect, honesty, peace, justice, etc. - in other words, values like those associated with humanism. But transculturalism also takes other forms of more materialist and anti-humanistic values that connect some cultures, and more recently populist nationalism. 
However, as Éigeartaigh and Berg (2010) argue, transculturalists who are able to adapt to new cultures and transcend their own by being able to function well within other cultures may be requirements for educational administration and leadership in increasingly diverse societies and in a more globalised world. And they need more than the popular 'intercultural communication' skills; engaging in meaningful social relationships interculturally requires a much deeper understanding and facility with values, attitudes, behaviour, mores, and standards.

Because culture plays a large part in the construction of our personal and professional identities affecting our dispositions and behaviour (Grant and Brueck 2011), being confronted with other ways of being can be disruptive, and needing to respond in other cultural forms can be regarded as threatening to identity. At this point, the notion of 'cosmopolitan' comes into play. On a global level there are degrees of 'cosmopolitanisation' taking place on individual and societal levels, and often including materialistic, individualistically self-centred, and pleasure fulfilment orientations (Portera 2011), not always welcome, consciously aware of, nor warranted due to globalisation effects and neo-colonisation, but there is also the 'cosmopolitanism' phenomenon of the conscious individual or group who intentionally interacts and participates in more than one culture and which may be a position adopted that carries a moral position of our obligations to others and valuing these differences, while not needing to achieve a consensus on principles and practices (Grant and Brueck 2011). It also, of course, can refer to someone who is able to easily participate in more than one culture - with significant differences in family structures and roles, notions of friendship, authority and obedience, and boundaries of behaviour - and has senses of attachment and belongingness to them - certainly abilities and states of being that historically the senior administrators within the Islamic empires had to be able to do.

In practical or applied terms, understanding of the Muslim communities that make up a large proportion of the world's population both in Muslim states and as minority groups in diverse societies, can contribute to multiculturalism and the complex practices and dynamics in intercultural social interactions and relations (Arrar and Haj-Yehia 2018). Its values and practices can contribute to better achieving inclusivity and diversity, which can help resolve educational problems of dropout, marginalisation (such as helping refugee groups integrate, not assimilate) into their new countries, and shaping citizens for a multicultural world in which people feel 
engaged and socially responsible for others regardless of their differences. Integrating the Islamic humanist tradition can also, as Tibi (2009) argues, can contribute to intercultural and transcultural graduate teaching in international educational administration. One possible pedagogical means is in aiming to achieve the fusion of horizons possible as Gadamer (1989) and Ricoeur (2004) have explained (themselves the result of a long tradition that predates its European forms).

On a larger, political, scale, there is potential benefit in internationalising educational administration and leadership so that it is more inclusive and tolerant, and sees value in practices from other parts of the world that may contribute to the field's development in ways in which historically, knowledge and skills have previously travelled enriching their host societies. In the contemporary period, plagued with problems of 'post-truth' politics (e.g., Kavanagh and Rich 2018; Levitin 2017) and in the current context of Islamophobia in the 'West' (Allan 2010; Esposito and Kalin 2011; Lean 2012; Sayyid and Vakil 2011; Zempi and Chakraborti 2014), there are many books that benefit from and have contributed to the development of misconceptions, misrepresentations and negative stereotyping of Islam, its principles, contributions to the intellectual history of the 'West' and its current practices for the vast majority of Muslims (Badran 2001; Shaheed 1999). In contrast, is a long tradition of peaceful relations that issued from the Islamic humanistic period in the writings of Al-Ghazali, Ibn Khaldun, and Ibn Rushd as well as the cosmopolitan and multicultural fabric of early periods of Islamic history during which a broad global view and appreciation of cultural differences was a valued source of knowledge and understanding (Euben 2006; Samier 2018), still evident in the work of contemporary Muslim scholars who emphasise this dimension of Islam in the Qur'an and Sunna (e.g., Abu-Nimer 2003; Esposito and Yilmaz 2010; Hashmi 2002; Sashedina 2007).

\section{References}

Abu-Nimer, M. (2003). Nonviolence and peace building in Islam: Theory and practice. Gainsville, FL: University Press of Florida.

Afsaruddin, A. (2007). The first Muslims: History and memory. Oxford: Oneworld.

Afsaruddin, A. (2016). Muslim views on education: parameters, purview, and possibilities. Journal of Catholic Legal Studies, 44(1), 143-178. 
al-Attas, S. (1980). The concept of education in Islam: a framework for an Islamic philosophy of education. Kuala Lumpur: ISTAC.

Aloni, N. (2007). Enhancing humanity: The philosophical foundations of humanistic education. Dordrecht: Springer.

Aloni, N. \& Weintrob, L. (Eds) (2017). Beyond bystanders: Educational leadership for a humane culture in a globalizing reality. Rotterdam: Sense.

Allan, C. (2010) Islamophobia. Farnham: Ashgate.

Al-Khalili, J. (2010). Pathfinders: The golden age of Arabic science. London: Penguin.

Al-Rodhan, N. (Ed.) (2012). The role of the Arab-Islamic world in the rise of the west: Implications for contemporary trans-cultural relations. Basingstoke: Palgrave Macmillan.

Amann, W., Pirson, M., Dierksmeier, C. (Eds) (2011). Business schools under fire: Humanistic management education as the way forward. Houndmills: Palgrave Macmillan.

Amann, W. \& Stachowicz-Stanusch, A. (2013). Introduction: Why the business world needs more integrity. In W. Amann \& A. Stachowicz-Stanusch (Eds), Integrity in organizations: Building the foundations for humanistic management (pp. 1-16). Houndmills: Palgrave Macmillan.

Antweiler, C. (2012). Inclusive humanism: Anthropological basics for a realistic cosmopolitanism. Göttingen: V \& R.

Apostolov, M. (2004). The Christian-Muslim frontier: A zone of contact, conflict or cooperation. London: Routledge.

Arar, K. \& Haj-Yehia, K. (2018). Perceptions of educational leadership in medieval Islamic thought. Journal of Educational Administration and History, 50(2), 69-81.

Badran, M. (2001). Understanding Islam, Islamism and Islamic feminism. Journal of Women's History, 13(1), 47-52.

Barkey, K. (2005). Islam and toleration: Studying the Ottoman imperial model. International Journal of Politics, Culture, and Society, 19, 5-19.

Barongo-Muweke, N. (2016). Decolonizing education: Towards reconstructing a theory of citizenship education for postcolonial Africa. Wiesbaden: Springer.

Beekun, R. (2012). Character centered leadership: Muhammad (p) as an ethical role model for CEOs. Journal of Management Development, 31(10), 1003-1020. 
Blackmore, J. (1999). Troubling women: Feminism, leadership, and educational change. Ballmore: Open University Press.

Box, R. (2005) Critical social theory in public administration. Armonk, NY: M. E. Sharpe.

Brown, J. (1994). Leadership education through humanistic texts and traditions: The Hartwick classic leadership cases. Journal of Leadership \& Organizational Studies, 1(3), 104-116.

Burns, J.M. (1978). Leadership. New York: Harper \& Row.

Cantle, T. (2012). Interculturalism: The new era of cohesion and diversity. New York: Palgrave Macmillan.

Copson, A. (2015). What is humanism? In A. Copson \& A. Grayling (Eds), The Wiley Blackwell handbook of humanism (pp. 1-33). Chichester: John Wiley \& Sons.

Copson, A. \& Grayling, A. (Eds) (2015). The Wiley Blackwell handbook of humanism. Chichester: John Wiley \& Sons.

Czarniawska-Joerges, B. \& Guillet de Monthoux, P. (eds) (1994) Good novels, better management: reading organizational realities. Chur: Harwood Academic.

Daiber, H. (2013). Humanism: A tradition common to both Islam and Europe. Filozofija I Društvo, 24(1), 293-310.

Dierksmeier, C., Amann, W., von Kimakowitz, E., Spitzeck, H., Pirson, M. (Eds) (2011). Humanistic ethics in the age of globality. Houndmills: Palgrave Macmillan.

Dossett, R. (2014). The historical influence of classical Islam on western humanistic education. International Journal of Social Science and Humanity, 4, 88-91.

Éigeartaigh, A., Berg, W. (2010) Editors' introduction: Exploring transculturalism. In W. Berg \& A. Éigeartaigh (Eds), Exploring Transculturalism (7-16). Wiesbaden: Springer.

ElKaleh, E. \& Samier, E.A. (2013). The ethics of Islamic leadership: a cross-cultural approach for public administration. Administrative Culture, 14(2), 188-211.

Esposito, J. \& Kalin, I. (2011). Islamophobia: The challenge of pluralism in the $21^{\text {st }}$ century. Oxford: Oxford University Press.

Esposito, J. \& Yilmaz, I. (Eds) (2010). Islam and peacebuilding. New York: Blue Dome Press.

Essa, A. (2010) Studies in Islamic civilization: The Muslim contribution to the renaissance. Herndon, VA: International Institute of Islamic Thought.

Euben, R. (2006). Journeys to other shore: Muslim and western travellers in search of knowledge. Princeton: Princeton University Press. 
Foster, W. (1986). Paradigms and promises: New approaches to educational administration. Buffalo, NY: Prometheus.

Gadamer, H. (1989). Truth and method. New York: Continuum.

Gagliardi, P. \& Czarniawska, B. (Eds) (2006). Management education and humanities. Cheltenham: Edward Elgar.

Giancola, J. \& Hutchison, J. (2005). Transforming the culture of school leadership: Humanizing our practice. Thousand Oaks: Corwin.

Gill, S. \& Niens, U. (2014). Education as humanization. Compare, 44(1), 10-31.

Gillies, D. (2013). Educational leadership and Michel Foucault. Abingdon: Routledge.

Goodman, L. (2003). Islamic humanism. Oxford: Oxford University Press.

Grant, C., Brueck, S. (2011) A global invitation: Toward the expansion of dialogue, reflection and creative engagement for intercultural and multicultural education. In C. Grant \& A. Protera (Eds) Intercultural and multicultural education (3-11). New York: Routledge.

Grayling, A. (2015). The good and worthwhile life. In A. Copson \& A. Grayling (Eds), The Wiley Blackwell handbook of humanism (pp. 87-93). Chichester: John Wiley \& Sons.

Greenfield, T. \& Ribbins, P. (1993). Greenfield on educational administration: Towards a humane science. London: Routledge.

Gunter, H. (2014). Educational leadership and Hannah Arendt. Abingdon: Routledge.

Günther, S. (2006). Be masters in that you teach and continue to learn: Medieval Muslim thinkers on educational theory. Comparative Education Review, 50(3), 367-388.

Habermas, J. (1984-1989). The theory of communicative action. Boston: Beacon Press.

Halstead, M. (2004). An Islamic concept of education. Comparative Education, 40(4), 517-529.

Hashmi, S. (Ed.) (2002). Islamic political ethics: Civil society, pluralism, and conflict. Princeton: Princeton University Press.

Hassi, A. (2012). Islamic perspectives on training and professional development. Journal of Management Development, 31(10), 1035-1045.

Kaplan, H. \& Tausky, C. (1977). Humanism in organizations: A critical appraisal. Public Administration Review, 37(2), 171-180.

Karim, K. \& Eid, M. (2014). Engaging the other: Public policy and western-Muslim intersections. Basingstoke: Palgrave Macmillan. 
Kashif, M., De Run, E., Rehman, M., Ting, H. (2015). Bringing Islamic tradition back to management development: a new Islamic Dawah based framework to foster workplace ethics. Journal of Islamic Marketing, 6(3), 429-446.

Kavanagh, J. \& Rich, M. (2018). Truth decay. Santa Monica, CA: RAND.

Kraemer, J. (1984). Humanism in the renaissance of Islam. Journal of the American Oriental Society, 104(1), 135-164.

Krämer, G. (2013) Pluralism and tolerance. In G. Bowering, P. Crone, W. Kadi, D. Stewart, M. Zaman (Eds) The Princeton encyclopaedia of Islamic political thought (419-427). Princeton: Princeton University Press.

Küng, H. (2008). Islam: Past, present and future. Oxford: Oneworld Publications.

Leaman, O. (1996). Islamic humanism in the fourth/tenth century. In S. Nasr \& O. Leaman (Eds), History of Islamic philosophy (pp. 295-306). London: Routledge.

Lean, N. (2012). The islamophobia industry: How the right manufactures rear of Muslims. London: Pluto Press.

Leoussi, A. (2000). Classical humanism and modern societies. Society, 37(5), 70-77.

Levitin, D. (2017). Weaponized lies: How to think critically in the post-truth era. New York: Dutton.

Ljamai, A. (2015). Humanistic thought in the Islamic world of the middle ages. In A. Copson \& A. Grayling (Eds), The Wiley Blackwell handbook of humanism (pp. 153-169). Hoboken, NJ: Wiley-Blackwell.

Loobuyck, P., Meer, N., Modood, T., Zapata-Barrero, R. (2016) Towards an intercultural sense of belonging together. In N. Meer, T. Modood, R. Zapata-Barrero (Eds), Multiculturalism and interculturalism: Debating the dividing lines. Edinburgh: University of Edinburgh Press.

López-Alves, F. \& Johnson, D. (Eds) (2018) Populist nationalism in Europe and the Americas. New York: Routledge.

Lumby, J. \& Coleman, M. (2007). Leadership and diversity: Challenging theory and practice in education. London: Sage.

Lyons, J. (2009). The house of wisdom: How the Arabs transformed western civilization. London: Bloomsbury.

Makdisi, G. (1981). The rise of colleges: Institutions of learning in Islam and the West. Edinburgh: Edinburgh University Press. 
Makdisi, G. (1990). The rise of humanism in classical Islam and the Christian west. Edinburgh: University Press.

March, A. (2009). Islam and liberal citizenship: The search for an overlapping consensus. Oxford: Oxford University Press.

Masood, E. (2009). Science \& Islam: A history. London: Icon Books.

Maxcy, S. \& Liberty, L. (1983) Should education leaders be humanistic? Journal of Thought, 18(4), 101-106

McLaren, P. \& Jamillo, N. (2007). Pedagogy and praxis in the age of empire: Towards a new humanism. Rotterdam: Sense.

Mir, A.M. (2010). Leadership in Islam. Journal of Leadership Studies, 4(3), 69-72.

Mohammed, J.A. (2013). The Islamic paradigm of morality: Toward a humanism approach. In S. Khan \& W. Amann (Eds), World Humanism (pp. 151-164). Houndmills: Palgrave Macmillan.

Morgan, M.H. (2007). Lost history: The enduring legacy of Muslim scientists, thinkers, and artists. Washington DC: National Geographic Society.

Mullen, C., English, F., Brindley, S., Ehrich, L., Samier, E.A. (2013). Neoliberal issues in public education. Interchange, 43(3), 181-186.

Nasr, S. (2001). Science and civilisation in Islam. Chicago: ABC International Group.

Nasr, S. (2006). Islamic philosophy from its origin to the present: Philosophy in the land of prophecy. Albany, NY: SUNY Press.

Niesche, R. (2018). Critical perspectives on educational leadership: a new 'theory turn'? Journal of Educational Administration and History, 50(3), 145-158.

Oldmeadow, H. (2004). Journeys east: $20^{\text {th }}$ century western encounters with eastern religious traditions. Bloomington, IN: World Wisdom.

Pirson, M. \& Kostera, M. (2017). Introduction to dignity and organization. In M. Kostera \& M. Pirson (Eds), Dignity and the organization (pp. 1-9). Houndmills: Palgrave Macmillan.

Portera, A. (2011). intercultural and multicultural education. In C. Grant \& A. Protera (Eds) Intercultural and multicultural education (12-30). New York: Routledge.

Plum, M. (2012). Humanism, administration and education: the demand for documentation and the production of a new pedagogical desire. Journal of Education Policy, 27(4), 491-507. 
Pormann, P. (2010). The continuing tradition of Arab humanism. International Journal of the Classical Tradition 17(1), 95-106.

Rhea, A. (2015). Leading and managing indigenous education in the postcolonial world. Abingdon: Routledge.

Ribbins, P. (2003). Biography and the study of school leaders: towards a humanistic approach. In M. Brundrett, N. Burton, R. Smith (Eds), Leadership in education (pp. 55-73). Thousand Oaks: Sage.

Ricoeur, P. (2004). Memory, history, forgetting. Chicago: University of Chicago Press

Roberts, (2000). Education, literacy, and humanization: Exploring the work of Paulo Freire. Westport: Bergin \& Garvey.

Said, E. (2004). Humanism and democratic criticism. New York: Columbia University Press.

Samier, E.A. (2005). Toward public administration as a humanities discipline: a humanistic manifesto. Administrative Culture, 6, 6-59.

Samier, E.A. (2017). The Islamic public administration tradition: Historical, theoretical and practical dimensions. Administrative Culture, 18(1), 53-71.

Samier, E.A. (2018). Philosophical and historical origins and genesis of Islamic global governance. In L. Pal \& M.E. Tok (Eds), Global governance and Muslim organizations (83-104). Cham: Palgrave Macmillan.

Samier, E.A. (forthcoming). Missing non-western voices on social justice for education: A postcolonial perspective on traditions of humanistic marginalized communities. In R. Papa (Ed.), Handbook on promoting social justice in education. New York: Springer.

Samier, E.A. \& Milley, P. (unpublished paper). 'What (Theoretically) is an International Education Administration Curriculum: Postcolonial Critiques for Sustaining National and Cultural Identities.'

Sashedina, A. (2007). The Islamic roots of democratic pluralism. Oxford: Oxford University Press. Sayyid, S. \& Vakil, A. (Eds) (2011). Thinking through islamophobia: Global perspectives. New York: Columbia University Press.

Schiele, J. (1990). Organization theory from an Afrocentric perspective. Journal of Black Studies, 21(2), 145-161.

Shaheed, F. (1999). Constructing identities: culture, women's agency and the Muslim world. International Social Science Journal, 51(159), 61-73. 
Sirry, M. (2011). The public role of Dhimmīs during 'Abbāsid times. Bulletin of the SOAS, 74(2), 187-204.

Smyth, J. (Ed.) (1989). Critical perspectives on educational leadership. New York: RoutledgeFalmer.

Spitzeck, H., Pirson, M., Amann, W., Kahn, S., Kimakowitz, E. (Eds) (2009). Humanism in business. Cambridge: Cambridge University Press.

Steiner, R. (2004). Human values in education. Great Barrington, MA: Anthroposophic Press.

Tampio, N. (2012). Kantian courage: Advancing the Enlightenment in contemporary political theory. Bronx, NY: Fordham University Press.

Thomson, P. (2017). Educational leadership and Pierre Bourdieu. Abingdon: Routledge.

Tibi, B. (2009). Bridging the heterogeneity of civilisations: reviving the grammar of Islamic humanism. Theoria, 56(120), 65-80.

Veugelers, W. (Ed.) (2011). Education and humanism: Linking autonomy and humanity. Rotterdam: Sense Publishers.

Von Kimakowitz, E., Pirson, M., Dierksmeier, C., Spitzeck, H., Amann, W. (2011). Introducing this Book and Humanistic Management. In E. Von Kimakowitz, M. Pirson, H. Spitzeck, C. Dierksmeier, W. Amann (Eds), Humanistic management in practice (pp. 1-12). Houndmills: Palgrave Macmillan.

Wong, K.-C. (1998). Culture and moral leadership in education. Peabody Journal of Education, 73(2), 106-125.

Yasin, R. \& Jani, M. (2013). Islamic education: the philosophy, aim, and main features, International Journal of Education and Research, 1(10), 1-18.

Zempi, I. \& Chakraborti, N. (2014). Islamophobia, victimization and the veil. Basingstoke: Palgrave Macmillan.

Zimmerman, J. (2012). Humanism and religion. Oxford: Oxford University Press. 